\title{
Competition between financial markets in Europe: what can be expected from MiFID?
}

\author{
Hans Degryse
}

Published online: 9 January 2009

(C) The Author(s) 2009. This article is published with open access at Springerlink.com

\begin{abstract}
The Markets in Financial Instruments Directive (MiFID) could be the foundation of new trading platforms in Europe. This contribution employs insights from the theoretical and empirical literature to highlight some of the possible implications of MiFID. In particular, we argue that more competition will lead to more liquid markets, reflected in lower bid-ask spreads and greater depth. It will also lead to innovation in incumbent markets and stimulate the design of new trading platforms. MiFID has already introduced more competition, as evidenced by the startup of Instinet Chi-X, the announcement of new initiatives, including Project Turquoise and BATS, and the reactions of incumbent exchanges.
\end{abstract}

Keywords Financial regulation · Market microstructure · MiFID · Trading systems

\section{JEL Classification G18}

\section{Introduction}

The organizational structure of a financial market specifies the procedures and rules for order flow and trades. The industrial organization of financial markets also determines how public and private information becomes incorporated into prices, and how market participants strategically interact with each other. Ultimately, market de-

This is an updated version of my inaugural lecture written for the occasion of my acceptance of the TILEC-AFM Chair on Financial Market Regulation at the University of Tilburg.

H. Degryse $(\bowtie)$

CentER-Tilburg University, TILEC, and European Banking Center, P.O. Box 90153,

5000 LE Tilburg, The Netherlands

e-mail: H.Degryse@uvt.nl 
sign and regulation shape the degree of investor participation, the competitiveness of financial markets, economic growth, and social welfare. ${ }^{1}$

Investors face a bewildering menu of choices for executing their trades. In the United States, many stocks are traded on alternative trading systems (ATSs) as well as on traditional exchanges. The Markets in Financial Instruments Directive (MiFID), recently implemented by all EU-Member States, allows the creation of new trading platforms. The Directive squeezes national stock exchanges from two sides. On the regulatory front, regulators call for greater transparency concerning, for example, clearing and settlement of trades, trading interests, and actual trades (see, e.g., The Economist 2006); on the customer front, clients can now threaten the exchanges with creating new trading platforms in their quest for the lowest possible fees.

Understanding how intermarket competition works, therefore, is increasingly important, even in Europe. In this paper, we review the theoretical and empirical literature on intermarket competition to study the possible implications of MiFID (see also Casey and Lannoo 2006; Davies 2008; Gomber and Gsell 2006). In particular, we deal with the issues of fragmentation and investor protection, market access, and the role of transparency in the functioning financial markets.

The remainder of the paper is organized as follows. In Sect. 2, we introduce MiFID and the possible trading platforms it allows. Section 3 deals with intermarket competition. Section 4 deals with issues related to market design and the expected impact of MiFID. Section 5 concludes.

\section{MiFID and trading platforms}

On April 21, 2004, the European Parliament and Council adopted the Markets in Financial Instruments Directive (MiFID), which had to be implemented in all EUMember countries by November 2007. The objective of MiFID is to foster a fair, competitive, transparent, efficient, and integrated European financial market by providing a regulatory environment that (i) offers high-quality investor protection and (ii) allows for the creation of new markets and services. MiFID (as well as its U.S.counterpart RegNMS ${ }^{2}$ ) intend to create a fair, level playing field for the different types of trading platforms.

The regulatory process of MiFID follows the Lamfalussy process, which involves four successive "levels" of implementation. MiFID itself is the so-called Level 1, providing the legislative framework. Level 2 has to do with implementing measures and details how the MiFID will work in practice. The Committee of European Securities Regulators (CESR) plays an important role in the entire process. For example, CESR

\footnotetext{
${ }^{1}$ See, e.g., Bernet (2005) for an economic analysis of financial market regulation.

${ }^{2}$ The implementation date of RegNMS was August 29, 2005; compliance with some of the rules was postponed until March 5, 2007. RegNMS divides trading venues into so-called fast markets and slow markets. The "trade-through rule" (i.e., the Order Protection Rule) only applies to fast markets, i.e., an order can be executed on a fast market even though a better price was available on a slow market. Gomber and Gsell (2006) argue that this provides incentives for slow markets to change into fast markets. For an analysis of RegNMS, see Gentzoglanis (2006). See Engelen (2006) for a complete description of the changes in the securities trading landscape in Europe and the United States.
} 
assists at Level 3 by translating the first two levels into national law and keeping an eye on harmonization. Finally, Level 4 involves supervising the consistent application and enforcement of these laws by the European Commission (more details can be found in Gomber and Gsell 2006).

MiFID is part of the Financial Services Action Plan (FSAP) and replaces the 1993 Investment Services Directive (ISD). Under the ISD, countries were allowed to employ the "concentration rule" (Art. 14(3) of the 1993 ISD), meaning that retail orders had to be executed on a regulated market, limiting the possibilities for creating new markets. Davies et al. (2005) review the trading systems in five large European countries and look at the implications of MiFID. They show that the development of financial markets in France, Spain, and Italy is heavily influenced by the concentration rule. In the absence of the concentration rule, trades can be executed on any trading platform allowed by MiFID. Other countries, such as Germany, have a "default rule," which requires financial intermediaries to execute orders on an exchange unless an investor opts out (see Gomber and Gsell 2006). Both the concentration rule and default rule are advantageous to the incumbent market.

MiFID removes the concentration rule and allows other trading platforms to compete with regulated markets for order flow. The Directive distinguishes three categories of trading services. The first two, "Regulated Markets" and "Multilateral Trading Facilities (MTFs)," are "multilateral systems operated and/or managed by a market operator, which brings together or facilitates the bringing together of multiple third-party buying and selling interests in financial instruments" (op. cit. Official Journal of the European Union L245/10). A regulated market, moreover, has clear and transparent rules regarding the trading of financial instruments. The third system is a "systematic internaliser (SI)." This is an "investment firm, which on an organized, frequent and systematic basis deals on own account by executing client orders outside a regulated market or multilateral trading facility."

\section{Intermarket competition: theory}

In MiFID, competition within a particular market design receives considerable attention. Many facets of market design, such as transparency, tick size, call versus continuous markets, and auction versus dealership markets, shape the competitiveness of markets. For an overview of these issues, the interested reader is referred to Amihud et al. (2006), Biais et al. (2005), De Jong and Rindi (2008), Hasbrouck (2007), and O’Hara (1995).

As financial securities may trade simultaneously on different platforms, a trader needs to decide how to allocate his or her orders. As a result, all these trading venues compete for order flow. The question, then, is how intermarket competition affects market quality. ${ }^{3}$

Pagano (1989), Chowdry and Nanda (1991), and Admati and Pfleiderer (1991) argue that due to liquidity externalities, trading has a natural tendency to concentrate

\footnotetext{
${ }^{3}$ The analysis of intermarket competition is related to the literature on competition between traditional financial markets (see, e.g., Pagano 1989; Chowdry and Nanda 1991; Glosten 1994; Easley et al. 1996; Bessembinder and Kaufman 1997; Parlour and Seppi 2003).
} 
in the market that is already most liquid. Therefore, it is difficult to "move liquidity" from one trading system to another, even when the new trading system is intrinsically better (see, however, the switch in liquidity from Liffe to Eurex in the German Bund in 1998, also called "market tipping" in the industrial organization literature). The "trade-through rule" in the United States implies that orders for listed companies should be executed at the best price. A trade-through happens when an order executes on a market despite there being a better price available on another market. The NYSE, enjoying a liquidity externality, therefore did not face much competition as all orders are forced to go to the most liquid exchange (Regulation NMS in 1994 in the United States has imposed this trade-through rule on all automated quotations that can be accessed automatically). The literature showing that consolidated markets should arise in equilibrium argues that there are costs to fragmentation. With fragmentation, bid-ask spreads tend to widen and exhibit greater price volatility (Harris 1993). However, heterogeneity in investor's tastes (e.g., willingness to trade, degree of immediacy, portfolio composition effects, informed versus liquidity traders) suggests that order flow may not be homogeneous. That is, some traders may search for differently organized trading systems that better satisfy their needs, leading to fragmentation (see, e.g., Madhavan 1995). Also, cream skimming may take place in that one market attracts the "uninformed" order flow. If this is the new market, then limit orders on the main market face more adverse selection problems and spreads may widen.

Are concentrated markets behaving competitively? Christie et al. (1994) and Christie and Schultz (1994), for example, have shown that imperfect competition in one market may prevail. They found that dealers on Nasdaq were colluding to maintain at least $\$ 0.25$ spreads by avoiding odd-eight quotes, a practice that disappeared after receiving attention from the media. Beneficial effects of intermarket competition may occur when liquidity suppliers on the "incumbent" exchange enjoy market power. A benefit of fragmentation, then, is increased competition resulting in greater market quality, for example, because bid-ask spreads become narrower. The introduction of an additional market introduces competitive pressures on the incumbent exchange. Also, even though the depth of the main market may decrease, the joint depth of both markets may increase (Glosten 1998).

Recently, some models have been developed to study how new trading platforms and traditional markets compete. Biais et al. (2006), for example, discuss how Internet technology reduces the costs of entry in financial markets. They show that perfect competition cannot be taken for granted even in modern financial markets. Intermarket competition can complement competition among traders within one trading system. They test this imperfect competition hypothesis by looking at order flow at the Island electronic communication network (ECN) and Nasdaq. To the extent that Nasdaq market makers are not behaving competitively, they expect to see more undercutting of the best market quotes when these are set at Nasdaq than when they are set at Island, and, indeed, find evidence of this. Foucault and Menkveld (2007) study a theoretical model where two exchanges compete and where only a fraction of brokers implement "smart order routing technology" to comply with trade-through rules. Their model reveals that joint depths will increase since submitting orders to another exchange somehow overcomes time priority. Also, the presence of more smart routers leads to more liquidity at the entrant market. 
Competition between traditional markets and crossing networks (CNs) is considered in Hendershott and Mendelson (2000) and in Degryse et al. (2008). A CN is a trading platform where buyers and sellers are matched at a prespecified time and trade at a price derived from the main market. These papers show that the presence of CNs generates two effects. First, competition may induce certain investors to submit orders that they would not have submitted otherwise (order creation effect), which improves liquidity. Second, if the $\mathrm{CN}$ is able to attract uninformed order flow, liquidity at the main exchange may decrease as this uninformed order flow cannot continue to be used to compensate losses faced when trading with informed traders.

\section{Market design: experience from the United States and the European Union}

MiFID has three main concerns: investor protection, market access, and transparency. In this section, we review the extant literature on each of these issues in order to formulate expectations about the impact of MiFID, which are then discussed in the next section.

\subsection{Investor protection: market fragmentation and the impact on market quality}

Investors should be protected in both concentrated and fragmented markets. As to concentrated markets, the concern has to do with the potential for imperfectly competitive behavior by market participants (see, e.g., Christie and Schultz 1994). In fragmented markets, investor protection relates not only to whether markets behave competitively, but also involves the question of whether best execution took place, i.e., was the order executed at the most favorable conditions for the retail investors. MiFID imposes best-execution obligations on investment firms. For professional clients, an investment firm is free to define in its execution policy what factors it will take into account. For retail clients, investment firms are required to deliver the best possible result in terms of price and costs; a regulation closely in line with the trade-through rule in the United States. The economic rationale for trade-through prohibition is that it discourages liquidity provision.

The stock exchanges in the United States have experienced considerable competition from ATSs. The most successful ATSs are ECNs, which enjoyed rapid growth after the introduction of the "Order Handling Rules" in 1997 (Sussman 2005). In 2004 , for example, they jointly attracted about $42 \%$ of market share in Nasdaq securities, and 3\% in NYSE listed stocks (see Stoll 2005). The joint market share of ECNs in U.S. equities was 11\% in Q2 of 2006 (estimates based on Aite Group report). Weston (2000) attributes the success of ECNs to two factors, the first of which is changing SEC regulations. For instance, the order handling rules increased competition because public limit orders became allowed to compete directly with Nasdaq market makers. Also, market makers posting orders on ECNs are now obliged to make those orders available to the public as well. This forces dealers to provide investors with greater access to ECNs. Moreover, ECNs have been more successful in attracting trade from Nasdaq. The intuition is that ECNs allow investors to trade directly with each other, eliminating the spread charged by dealers. The NYSE is 
already an auction market (with a specialist) and enjoys an incumbency advantage due to liquidity externality and the prevailing "trade-through provision." Second, advances in technology have played a tremendous role. The U.S.-based trading systems were less advanced compared to many European exchanges, thus allowing the ECNs to attract a significant part of the market.

A set of empirical papers investigates the impact of ECNs on the market quality of traditional exchanges in the United States, mainly Nasdaq. ${ }^{4}$ While it is not easy to summarize the findings of all these studies, we can state that (1) more trading on ECNs leads to tighter bid-ask spreads and greater depth on Nasdaq, (2) ECNs allow for lower transaction costs and this does not stem from attracting only the "easier" trades, (3) ECNs contribute to price discovery, and (4) ECNs may induce higher adverse selection costs.

The empirical literature analyzing $\mathrm{CNs}$ is more sparse, due to the fact that $\mathrm{CNs}$ are dark liquidity pools and often proprietary. Gresse (2006) studies the impact of the POSIT CN on the liquidity of the dealer market segment of the London Stock Exchange (SEAQ) for a cross section of U.K. and Irish mid-cap stocks. She finds that POSIT has a market share of total trading volume in these stocks of about 1-2\%. Its probability of execution, though, is still low (2-4\%). Furthermore, she reports that activity at POSIT does not have a detrimental effect on liquidity on SEAQ.

Conrad et al. (2003) use proprietary data on trades by institutional investors in the United States who choose between three trading platforms: CNs, ECNs, and traditional brokers. CNs have substantially lower realized execution costs as compared to brokers, mainly stemming from the lower commissions on CNs and the absence of spread costs and direct price impact costs. Næs and Ødegaard (2006) examine the trades of a single institution, the Norwegian Petroleum Fund. Their results show that although the Conrad et al. (2003) cost differential is confirmed, it is not clear that this differential persists in the presence of private information (which may affect the probability of crossing). Hence, measured low costs in CNs may be fully offset by substantial costs of nontrading due to adverse selection in the CNs.

Finally, the coexistence of different trading systems has also implied that the "National Best Bid and Offer" for an average active stock is nonpositive $10.58 \%$ and $4.05 \%$ of the time on, respectively, the Nasdaq and the NYSE intermarkets. Shkilko et al. (2006) attribute these nonpositive spreads to competitive trading practices in contemporary fragmented markets. When European financial markets become more fragmented, similar situations might occur.

\subsection{Market access}

The MiFID, in line with the ISD, establishes an EU passport for investment firms. Member States are required to ensure that investment firms from other Member States have the right to access (1) the regulated markets in their country, and (2) the clearing and settlement systems.

\footnotetext{
${ }^{4}$ See Huang (2002), Hendershott and Mendelson (2000), Simaan et al. (2003), Domowitz (2001), Barclay et al. (2003), Weston (2000), Conrad et al. (2003), Benhamou and Serval (2000), Domowitz et al. (2001), Domowitz and Steil (1999), and Næs and Ødegaard (2006). Other examples of measuring transaction costs include Ranaldo (2001, 2002).
} 
Important is whether investors have market access at equal terms, and whether smart order routing technology may bring markets together by providing technology that optimally executes orders on several markets. This technology works only when markets can be accessed at any time at similar conditions. As already mentioned, Foucault and Menkveld (2007) model how smart routers may improve liquidity. They analyze the liquidity of Dutch stocks on Euronext Amsterdam with the introduction of EuroSETS and the presence of smart routers. They find that joint depth increased after the introduction of EuroSETS. They also find that bid-ask spreads are lower on EuroSET for stocks exhibiting more smart routers. Market access to new trading platforms induced by smart routers seems a key to success.

\subsection{Transparency}

The degree of transparency of financial markets influences traders' submission strategies. A distinction is made between pretrade transparency and posttrade transparency. Pretrade transparency refers to the availability of information on outstanding order flow accumulated in the order book or dealer quotes before orders are submitted. This information concerns quotes and trading interest, and can contain information on different trading platforms. Posttrade transparency deals with the availability of information about executed trades.

Stock exchanges differ widely as to the transparency of their financial markets. The MiFID regulates what information should be disclosed to market participants for stocks that are listed on regulated markets. In particular, MiFID requires that for the MTFs, as well as for the regulated markets, real time interests be made available to investors. For quote-driven markets, this is the best bid and offer of every market maker, whereas for order-driven markets, it is the five best bids and offers. Also, systematic internalizers are required to provide quotes to market participants for the most liquid stocks. Posttrade information must be submitted in real time and contain the time stamp, the instrument traded, the price, the quantity, and the execution venue..$^{5}$

How does unequal transparency affect intermarket competition? In contrast to ECNs, which basically function as a transparent limit order book, CNs are extremely opaque, both in terms of pretrade and posttrade transparency. Pretrade transparency on one market allows for "free-riding" in other markets and by crossing networks in particular (Hendershott and Mendelson 2000). Degryse et al. (2008) show that the degree of opaqueness determines traders' willingness to opt for the $\mathrm{CN}$. In their work, they emphasize that, on the one hand, a pretrade transparent $\mathrm{CN}$ invites traders to hit visible market liquidity and that investors may be more willing to opt for the $\mathrm{CN}$ as they anticipate their order to invite counterparties to benefit from the created and visible liquidity. On the other hand, however, opaque $\mathrm{CN}$ systems allow anonymous trading. Thus, large order imbalances in the $\mathrm{CN}$ do not alarm the base market and do not generate an adverse price impact.

There are only a few empirical studies investigating the impact of transparency changes. One such paper finds negative market quality effects in the presence of greater pretrade transparency. Madhavan et al. (2005) study the dissemination on the

${ }^{5}$ See, e.g., the AFM website: http://www.afm.nl. 
Toronto Stock Exchange of limit order book data on April 12, 1990. On that date, the stock exchange started to display limit order book data on the "floor" trading segment and on the "automatic trading segment" (CATS). Madhavan et al. find a negative impact on market quality. The bid-ask spreads increase on the Toronto Stock Exchange, but to a greater degree for "floor trading" than for "CATS." Also, the adverse selection component of the bid-ask spread increases in both "floor" and "CATS" stocks. While depth remains unaffected, there is a significant increase in volatility. Finally, Madhavan et al. (2005) report a negative stock market reaction as there was a decline in stock prices.

However, other papers have found a positive impact of pretrade transparency on market quality. Boehmer et al. (2005) study the introduction of the OpenBook on the NYSE in January 2002. This greater transparency implies that traders off the NYSE floor observe depth in the limit order book in real time at each price level. Boehmer et al. (2005) find that this has an impact on trading strategies in that traders appear to manage the exposure of their orders (higher cancellation rates and shorter time to cancellation) and that "specialist" participation declines. The informational efficiency of prices increases as there are smaller deviations of transaction prices from the efficient price. Finally, liquidity increases as effective spreads decline and limit order book depth becomes greater.

One paper looks at the impact a pretrade transparency change in one market has on other markets. Hendershott and Jones (2005) study what happened when Island decided to stop displaying the limit order book and "go dark" on the three most active exchange traded funds on September 23, 2002, to avoid the Regulation ATS. Under this regulation, when limit order book data are made available to some players, they must be made available to all interested parties. Island was at that time the most important trading venue in these instruments. The impact of Island going dark was a drop of its market share by about half, and price discovery shifting to other markets (Instinet, Archipelago, AMEX, NYSE). The effective and realized spreads increased on Island and decreased on the other markets, with the net overall effect being ambiguous. On October 31, 2003, Island decided to redisplay the quotes. Spreads fell, but not back to their original level.

Gemmill (1996) investigates changes in posttrade transparency on the London Stock Exchange. He studies liquidity for three different publication regimes. From 1987 to 1988 , dealers were required to immediately report their block trades, from 1991 to 1992 they had to do so within 90 minutes, and from 1989 to 1990 they had 24 hours in which to do so. Disclosure regime did not appear to affect liquidity on the London Stock Exchange.

\section{Conclusion}

The empirical evidence, chiefly from the United States, shows that market quality improves when financial markets coexist. This result is particularly strong for competition between ECNs and dealer markets like Nasdaq; it is less pronounced, however, for competition between CNs and other trading systems. We therefore can conclude that competition from new trading platforms, as permitted by MiFID, will not harm 
market quality. However, most European exchanges already exhibit an auction market design using a limit order book. Competition between ATSs and the NYSE, which also employs a limit order book, has not been entirely successful due to presence of the "trade-through rule": orders have to go to the most liquid market. New trading platforms in Europe might have a chance of success, too, as MiFID also imposes a best-execution rule.

MiFID aims at providing a level playing field for trading by imposing uniform transparency requirements, removing the concentration rule, and allowing new trading platforms. MiFID therefore provides opportunities for both suppliers and demanders of liquidity. Our review of theory and empirical evidence reveals a number of insights on how best to reap the benefits of competition and innovation. A first insight relates to investor protection and the interpretation of best execution. The "trade-through prohibition" provides a natural advantage for the incumbent market. A best-execution policy that simply states that execution at the established market is sufficient, or that implies discriminatory access to alternative markets, may introduce entry barriers for new trading platforms. Similarly, a best-execution policy that considers only a new trading platform would also hamper competition. A second insight has to do with market access. Investors should be able to connect and pool the liquidity in the different trading platforms. This connectivity allows for beneficial effects from smart routers and algorithmic trading. Finally, transparency combined with greater availability of technology seems to improve liquidity. Indeed, although earlier studies showed negative effects of greater transparency, the most recent evidence suggests that greater transparency promotes liquidity. This reversal in results could be due to technology. Current technology allows investors to closely monitor the limit order book. As argued by Davies et al. (2005), the effects of greater transparency are perhaps most clearly seen in the United Kingdom and Germany.

The first results from MiFID are already apparent and quite positive-witness the introduction of Instinet Chi-X, Project Turquoise, and BATS and the reactions by incumbent exchanges ${ }^{6}$ (for more detail, see Davies 2008). MiFID is a principlesbased approach that leaves room for interpretation at the implementation stage. The market microstructure literature reveals that often even very minor changes can have important market-wide consequences. European supervisors and regulators should keep this bit of wisdom in mind and closely watch future developments.

Acknowledgements Many thanks to an anonymous referee, the editor, Jan Bouckaert, Frank de Jong, Jérémie Lefebvre, and Steven Ongena for their comments on a previous draft.

\footnotetext{
${ }^{6}$ The incumbent European exchanges have reacted and anticipated to the new competitive threats of MTFs and SIs in a number of ways. A first reaction is by (attempts at) mergers and acquisitions among themselves. The demutualization of stock exchanges and their public listing allows exchanges to merge more easily. A second reaction is to "preempt" the market by changing their market design or their pricing policies. Euronext, for example, has (1) created its own MTF (Alternext), (2) started to offer SI-type services to investment firms for which it takes care of reporting to supervisors, (3) introduced applications where the price-time priority is replaced by price-investment firm priority, (4) initiated partnerships to introduce a European "dark pool" (Smart Pool), and (5) reduced fees for algorithmic traders in an attempt to win them back or prevent them from switching to alternative platforms (win-back pricing).
} 
Open Access This article is distributed under the terms of the Creative Commons Attribution Noncommercial License which permits any noncommercial use, distribution, and reproduction in any medium, provided the original author(s) and source are credited.

\section{References}

Admati, A., Pfleiderer, P.: Sunshine trading and financial market equilibrium. Rev. Financ. Stud. 4, 443481 (1991)

Amihud, Y., Mendelson, H., Pedersen, L.H.: Market Microstructure and Asset Pricing. Foundations and Trends in Finance. Now Publishers, Boston (2006)

Barclay, M., Hendershott, T., McCormick, T.: Competition among trading venues: information and trading on electronic communications networks. J. Finance 58, 2637-2666 (2003)

Benhamou, E., Serval, T.: On the competition between ECNs, stock markets and market makers. Financial Markets Group discussion paper (2000)

Bernet, B.: Towards an economic analysis of financial markets regulation. Financ. Mark. Portf. Manag. 19, 313-322 (2005)

Bessembinder, H., Kaufman, H.M.: A cross-exchange comparison of execution costs and information flow for NYSE-listed stocks. J. Financ. Econ. 46, 293-319 (1997)

Biais, B., Glosten, L., Spatt, C.: Market microstructure: a survey of microfoundations, empirical results, and policy implications. J. Financ. Mark. 8, 217-264 (2005)

Biais, B., Bisière, C., Spatt, C.: Imperfect competition in financial markets: ISLAND versus NASDAQ. Mimeo (2006)

Boehmer, E., Saar, G., Yu, L.: Lifting the Veil: an analysis of pre-trade transparency at the NYSE. J. Finance 60, 783-815 (2005)

Casey, J.P., Lannoo, K.: The MiFID revolution: a policy view. Compet. Regul. Netw. Ind. 1, 515-534 (2006)

Chowdry, B., Nanda, V.: Multimarket trading and market liquidity. Rev. Financ. Stud. 3, 483-511 (1991)

Christie, W., Schultz, P.H.: Why do NASDAQ market makers avoid odd-eighth quotes? J. Finance 49, 1813-1840 (1994)

Christie, W., Harris, J.H., Schultz, P.H.: Why did NASDAQ market makers stop avoiding odd-eighth quotes? J. Finance 49, 1841-1860 (1994)

Conrad, J., Johnson, K., Wahal, S.: Institutional trading and alternative trading systems. J. Financ. Econ. 70, 99-134 (2003)

Davies, R.: MiFID and a changing competitive landscape. Mimeo (2008)

Davies, R., Dufour, A., Scott-Quinn, B.: The MiFID: competition in a new European equity market regulatory structure. Mimeo (2005)

De Jong, F., Rindi, B.: The Microstructure of Financial Markets. Cambridge University Press, Cambridge (2008, forthcoming)

Degryse, H., Van Achter, M., Wuyts, G.: Dynamic order submission strategies with competition between a dealer market and a crossing network. J. Financ. Econ. (2008, forthcoming)

Domowitz, I.: Liquidity, transaction costs, and reintermediation in electronic markets. Working paper (2001)

Domowitz, I., Steil, B.: Automation, trading costs and the structure of the securities trading industry. Brookings-Wharton papers on Financial Services (1999)

Domowitz, I., Glen, J., Madhavan, A.: Global equity trading costs. Working paper (2001)

Easley, D., Kiefer, N.M., O’Hara, M.: Cream-skimming or profit-sharing? The curious role of purchased order flow. J. Finance 51, 811-833 (1996)

Engelen, P.J.: Changes in securities trading landscape in Europe and the US. Compet. Regul. Netw. Ind. 1, 439-451 (2006)

Foucault, T., Menkveld, A.: Competition for order flow and smart order routing systems. J. Finance (2007, forthcoming)

Gemmill, G.: Transparency and liquidity: a study of block trades on the London stock exchange under different publication rules. J. Finance 51, 1765-1790 (1996)

Gentzoglanis, A.: Reg NMS and competition in the alternative trading systems in the US. Compet. Regul. Netw. Ind. 1, 497-514 (2006)

Glosten, L.: Is the electronic open limit order book inevitable? J. Finance 49, 1127-1161 (1994) 
Glosten, L.: Precedence rules. Working paper, Columbia University (1998)

Gomber, P., Gsell, M.: Catching up with technology - the impact of regulatory changes of ECNs/MTFs and the trading venue landscape in Europe. Compet. Regul. Netw. Ind. 1, 537-557 (2006)

Gresse, C.: The effect of crossing-network trading on dealer market's bid-ask spreads. Eur. Financ. Manag. 12, 143-160 (2006)

Harris, L.: Consolidation, fragmentation, segmentation and regulation. Financ. Mark. Inst. Instrum. 5, 1-28 (1993)

Hasbrouck, J.: Empirical Market Microstructure. Oxford University Press, Oxford (2007)

Hendershott, T., Jones, C.: Island goes dark: transparency, fragmentation, and regulation. Rev. Financ. Stud. 18, 743-793 (2005)

Hendershott, T., Mendelson, H.: Crossing networks and dealer markets: competition and performance. J. Finance 55, 2071-2115 (2000)

Huang, R.: The quality of ECNs and Nasdaq market makers quotes. J. Finance 57, 1285-1317 (2002)

Madhavan, A.: Consolidation, fragmentation and the disclosure of trading information. Rev. Financ. Stud. 8, 579-603 (1995)

Madhavan, A., Porter, D., Weaver, D.: Should securities markets be transparent? J. Financ. Mark. 8, 266288 (2005)

Næs, R., Ødegaard, B.: Equity trading by institutional investors. To cross or not to cross? J. Financ. Mark. 9, 79-99 (2006)

O’Hara, M.: Market Microstructure Theory. Blackwell, Cambridge (1995)

Pagano, M.: Trading volume and asset liquidity. Q. J. Econ. 104, 255-274 (1989)

Parlour, C., Seppi, D.: Liquidity-based competition for order flow. Rev. Financ. Stud. 16, 301-343 (2003)

Ranaldo, A.: Intraday market liquidity on the Swiss stock exchange. Financ. Mark. Portf. Manag. 15, 309-327 (2001)

Ranaldo, A.: Transaction costs on the Swiss stock exchange. Financ. Mark. Portf. Manag. 16, 53-68 (2002)

Shkilko, A.V., Van Ness, B.F., Van Ness, R.A.: Locked and crossed markets on Nasdaq and the NYSE. J. Financ. Mark. (2006, forthcoming)

Simaan, Y., Weaver, D., Whitcomb, D.: The quotation behavior of ECNs and Nasdaq market makers. J. Finance 58, 1247-1267 (2003)

Stoll, H.R.: Electronic trading in stock markets. Working paper, Vanderbilt University (2005)

Sussman, A.: Trends and opinions on algorithmic trading. Tabb Group Research Report (2005)

The Economist: Stock exchanges: a war on two fronts. November 18, pp. 72-76 (2006)

Weston, J.: Competition on the Nasdaq and the impact of recent market reforms. J. Finance 55, 2565-2598 (2000)

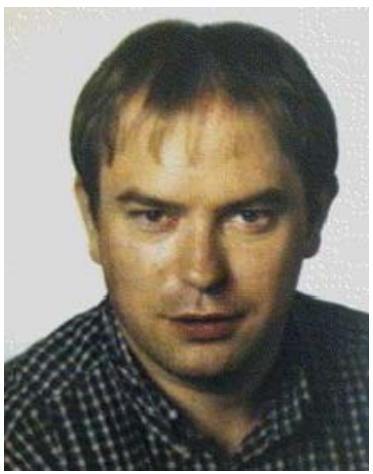

Hans Degryse is professor of financial intermediation and markets at Tilburg University since 2005. He also holds the TILEC-AFM chair on financial market regulation. In addition, he is a research fellow at the CESIfo in Munich. He received a Ph.D. in Economics from Leuven in 1995. He has published in many journals including the Journal of Finance, the Journal of Financial Economics, the Journal of Financial Intermediation, Economic Journal and the Review of Finance. He has been consultant to the Belgian Central Bank, the ECB, and the OECD. 